all ages, including the influence of biochemical and bacteriological factors, and the role of fluorine, calcium and other elements in tooth formation and resistance to decay. This expenditure amounts to about 1 per cent of the Council's total expenditure on medical research. He understood that the value of hand-produced sugar confectionery, including chocolate confectionery, in 1959 , was $£ 193$ million and that the total consumption, based on prices paid by consumers, was $£ 259$ million. There is also some $£ 750,000$ a year spent on dental work in the Universities through the University Grants Committee, but he agreed that even taking into account work done in private institutions, the total effort falls far short of the country's needs. Lord Hailsham pointed out that one limiting factor is the availability of suitable research workers, and that the school dental service, betterment of which could do much to improve the dental health of the nation, is already handicapped by the shortage of dentists.

\section{Output of Power in Great Britain}

In his presidential address to the British Electrical Power Convention on May 30, Viscount Chandos, discussing "Electricity - the New Horizon", emphasized the great problems with which the increase in the capacity of generators faces the electricity manufacturers. The five main manufacturers of heavypower plant in Great Britain had a capacity of not less than 7,000 MW. a year and the probable demand for new additions to plant for the grid might be put at about 2,750 MW. a year, leaving 4,250 MW. for export. The competitive power of Britain must be largely governed by competitive wages, and if these plants had to work appreciably below 7,000 MW. a year the industry would feel the pinch. To some extent, he pointed out, the amount of power that Britain has to sell for export must depend on the development of power in what are now described as under-developed countries, and in this connexion, while noting the general shortage of capital, Lord Chandos protested against the tendency to lend to uncredit-worthy countries. Besides avoiding inflation, Britain should seek to create new credit to match the ever-increasing sources of wealth which science and technology had to offer. Besides the new horizons in the generation of electricity, there were new horizons in its application. Its use in the home, the mounting use of fractional horse-power motors, its use in lighting and in communications, whether by transport or telephone, offered possibilities which it was as yet difficult to discern precisely, quite apart from the effect of such developments on all aspects of living. Finally, referring to the fact that the European Common Market would lead to some large industrial amalgamations, which would have at hand a larger domestic market than could ever be hoped to be found in Britain or even in the European Free Trade Area, Lord Chandos emphasized the danger of wasting or misusing technical man-power, instancing the waste involved in submitting four tenders for one nuclear power station. Without undermining competition, he suggested attempts should be made to co-operate more in fundamental research ov $\ni$ a wide field and the industry should not be open to the charge of having half a dozen different research establishments, using perhaps twice the necessary technical effort, to extend the frontiers of our knowledge in relation to one particular port of the electrical industry.

\section{The Swedish National Committee for Physics}

The tenth general physics conference of the Swedish National Committee for Physics was held at the Royal Institute of Technology in Stockholm during June 1-3, 1959. In addition to a large number of contributed papers presented at twenty sessions, special guest lectures were delivered by H. MaierLeibnitz (Munich), who spoke about the research programme of the Munich reactor, and by C. J. Gorter (Kamerlingh Onnes Laboratory, Leyden), who discussed the problem of orienting atomic nuclei at low temperatures. Introductory papers were given by $O$. Klein on the systematics of elementary particles and by $H$. Alfvén on plasma physics and magnetohydrodynamies. Abstracts of all the contributed papers are published in the March issue of Arkiv för Physik $(16,481 ; 1960)$. Most of the papers deal with aspects of plasma and nuclear physics, but several are concerned with the infra-red examination of semiconductors. A number of new instruments and devices are reported. At the University of Uppsala a high-precision curved quartz crystal gamma spectrometer of the Du Mond type has been constructed and used for precision measurements of the $K$ - and $L$-levels in the heavier elements. Optical instruments include shearing interferometers for the examination of spectral line broadening (Royal Institute of Technology, Stockholm) and a photoelectric device for measuring spectrograms (University of Lund). At the Nobel Institute of Physics, Stockholm, a new method for measuring half-lives of excited states in the region $<10^{-10}$ sec., based on the high-frequency deflexion of conversion electrons, has been tested. As a first step in a programme of development of large bubble chambers to be used at the 1,200-MeV. electron-synchrotron at the University of Lund, a 2 -in. cylindrical chamber with vertical windows has been constructed. This University has also produced a cylindrical dose-rate meter for X-rays which is of small dimensions (2-mm. diameter) and which utilizes a $p-n$ junction in a gallium arsenide semiconductor. The meter has a relatively low impedance and fast response, which makes it well suited for control measurements during $\mathrm{X}$-ray therapy.

\section{Plankton at Freetown, Sierra Leone}

IN work on the plankton of the estuary and the immediate offshore waters of the Sierra Leone River (Colonial Office. Fishery Publications, No. 13. Pp. iv +48 . London: H.M. Stationery Office, 1960. 35s. net) Mr. V. Bainbridge was faced with a two-part problem imposed by the alternation of wet and dry seasons, the resulting conditions differing very considerably. Throughout the wet season there is a tendency towards a two-layered transport system, with brackish water flowing seawards on the surface and more saline water flowing into the estuary along the bottom. These conditions are, however, scarcely detectable in tho dry season. During the wet season most of the phytoplankton within the estuary consisted of benthic forms and, at the offshore station, diatoms were relatively scarce. Very small numbers of diatoms at the offshore station during the dry season were coincident with a large standing crop of phytoplankton within the estuary, comparable in abundance with those found in Long Island Sound and the Rio de Vigo. The zooplankton species appeared to be subjected to a flushing out from the 